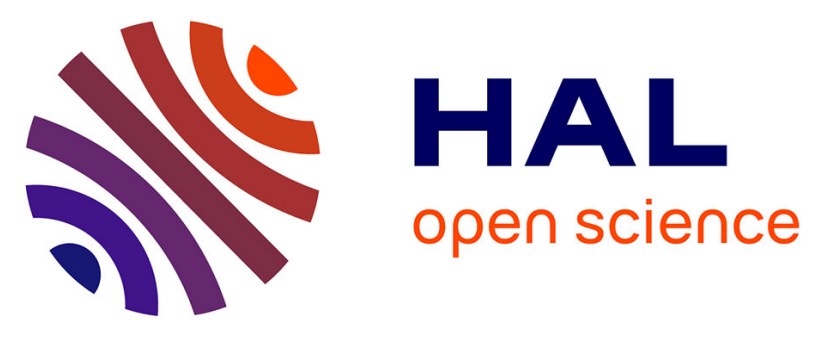

\title{
Revealing the Chemical Form of "Invisible" Gold in Natural Arsenian Pyrite and Arsenopyrite with High Energy-Resolution X-ray Absorption Spectroscopy
} Margarita Merkulova, Olivier Mathon, Pieter Glatzel, Mauro Rovezzi, Valentina Batanova, Philippe Marion, Marie-Christine Boiron, Alain Manceau

\section{- To cite this version:}

Margarita Merkulova, Olivier Mathon, Pieter Glatzel, Mauro Rovezzi, Valentina Batanova, et al.. Revealing the Chemical Form of "Invisible" Gold in Natural Arsenian Pyrite and Arsenopyrite with High Energy-Resolution X-ray Absorption Spectroscopy. ACS Earth and Space Chemistry, 2019, 3 (9), pp.1905-1914. 10.1021/acsearthspacechem.9b00099 . hal-02314773

\author{
HAL Id: hal-02314773 \\ https://hal.science/hal-02314773
}

Submitted on 14 Oct 2019

HAL is a multi-disciplinary open access archive for the deposit and dissemination of scientific research documents, whether they are published or not. The documents may come from teaching and research institutions in France or abroad, or from public or private research centers.
L'archive ouverte pluridisciplinaire HAL, est destinée au dépôt et à la diffusion de documents scientifiques de niveau recherche, publiés ou non, émanant des établissements d'enseignement et de recherche français ou étrangers, des laboratoires publics ou privés. 


\title{
Revealing the chemical form of "invisible" gold in natural arsenian pyrite and arsenopyrite with high energy-resolution X-ray absorption spectroscopy
}

\author{
Margarita Merkulova ${ }^{1, *, \S}$, Olivier Mathon ${ }^{1}$, Pieter Glatzel ${ }^{1}$, Mauro Rovezzi $^{1}$, Valentina Batanova ${ }^{2}$, \\ Philippe Marion ${ }^{3}$, Marie-Christine Boiron ${ }^{4}$, Alain Manceau ${ }^{2, *}$
}

${ }^{1}$ European Synchrotron Radiation Facility (ESRF), 38000 Grenoble, France

${ }^{2}$ Univ. Grenoble Alpes, CNRS, ISTerre, 38058 Grenoble, France

${ }^{3}$ Univ. Lorraine, ENSG, CNRS, GeoRessources Lab, 54000 Nancy, France

${ }^{4}$ Univ. Lorraine, CNRS, GeoRessources, 54000 Nancy, France

${ }^{\S}$ Present address: Faculty of Sciences, Vrije Universiteit Amsterdam, De Boelelaan 1085, $1081 \mathrm{HV}$, Amsterdam, The Netherlands

*Corresponding Authors :

*margarit.merkulova@gmail.com

*alain.manceau@univ-grenoble-alpes.fr

Key words: “invisible” gold, HR-XANES, HR-EXAFS, pyrite, arsenopyrite

\begin{abstract}
The structural chemistry of gold in arsenian pyrite $\left(\mathrm{FeS}_{2}\right)$ and arsenopyrite $(\mathrm{FeAsS})$ is as yet unknown, despite the economic importance of this element and its potential recovery from lowgrade ores and mine tailings. The systematic co-occurrence of $\mathrm{Au}$ and $\mathrm{As}$ poses a challenge for measuring the $\mathrm{Au} \mathrm{L}_{3}$-edge X-ray absorption spectra because the Au La emission line is partly (pyrite) to totally (arsenopyrite) obscured by the intense As Ka line. Utilizing a newly developed high luminosity multi-crystal analyzer, in combination with the capabilities of a synchrotron-based microprobe, the Au L $\alpha$ and As Ka lines were separated and the Au L3-edge XANES and EXAFS spectra of chemically-bound $\mathrm{Au}$ in arsenian pyrite and arsenopyrite from gold deposits measured for the first time. High energy-resolution XANES (HR-XANES) shows that gold has a formal oxidation state of $1+$ in the two sulfides, but a distinct bonding environment. In arsenian pyrite with a point $\mathrm{Au} / \mathrm{As}$ atomic ratio of 0.14 (0.37 wt ratio) and lacking geochemical correlation between the concentrations of $\mathrm{Au}$ and $\mathrm{As}, \mathrm{Au}$ occupies the $\mathrm{Fe}$ site and is bonded to six $\mathrm{S}$ atoms at $2.41 \AA$, as
\end{abstract}


determined by HR-EXAFS. In contrast, in arsenopyrite with a point Au/As atomic ratio of $7.1 \times 10^{-3}$ (0.02 wt ratio) and exhibiting a Au-As correlation, octahedrally coordinated Au is bonded only to As atoms at $2.52 \AA$. The results reveal the atomic-scale structure of gold and its intricate geochemical association with arsenic in auriferous Fe sulfides. This work demonstrates that high energy-resolution X-ray absorption spectroscopy on synchrotron X-ray microprobes can illuminate the structural chemistry of trace elements in chemically complex Earth and planetary materials.

\section{INTRODUCTION}

Arsenian pyrite, and to a lesser extent arsenopyrite, are the main auriferous minerals in refractory gold ores. They have been described in numerous orogenic and Carlin-type gold deposits, in which gold is usually referred to as "invisible" gold. ${ }^{1-9}$ Remarkably high concentrations of Au, up to 0.9 $\mathrm{wt} \%$, in both pyrite ${ }^{7}$ and arsenopyrite ${ }^{4,10}$ have been reported. Gold is present in two forms in pyrite and arsenopyrite, as micro- to nano-sized inclusions of metallic $\mathrm{Au}$ nanoparticles $\left(\mathrm{Au}^{0}\right)$ and incorporated in the crystal structure. 5, 6, 9-24

Arsenic is considered as essential for incorporation of invisible gold, the concentrations of the two elements being generally correlated positively in pyrite $2,7,10,17,25,26$ and arsenopyrite. ${ }^{10,27}$ However, weak or lack of correlation has been also observed in both pyrite $5,7,8,10,18,28$ and arsenopyrite. ${ }^{28}$ Covariation of $\mathrm{Au}$ and As is considered to be limited by the solubility of Au in the two sulfides. Reich et al. ${ }^{7}$ defined the empirical atomic solubility limit of Au in arsenian pyrite formed at temperatures between 150 and $250{ }^{\circ} \mathrm{C}$ as $[\mathrm{Au}]_{\mathrm{at} .}=0.02 \times[\mathrm{As}]_{\mathrm{at} .}+4 \times 10^{-5}$, on the basis of several hundreds secondary-ion mass spectrometry (SIMS) analyses and electron probe microanalyses (EPMA) of arsenian pyrite from Carlin-type and epithermal deposits. The maximum Au/As atomic ratio of 0.02 corresponds to $0.5 \mathrm{wt} \% \mathrm{Au}$ at $10 \mathrm{wt} \%$ As and to $500 \mu \mathrm{g} / \mathrm{g} \mathrm{Au}(\mathrm{ppm})$ at $1 \mathrm{wt} \%$ As. High $\mathrm{Au}$ concentrations above the solubility-limit represent elemental Au occurring as nanonuggets. This relationship suggests that the maximum amounts of chemically-bound $\mathrm{Au}$ is a crystal chemical property of the solid independent of the geochemical condition of pyrite formation. The same authors estimated the maximum concentration of Au in stoichiometric arsenopyrite to be $2 \mathrm{wt} \%$.

Metallic gold nanoparticles have been imaged by HAADF-STEM, ${ }^{6}$ and detected by SIMS and LA-ICP-MS depth-profiling of Au concentration. ${ }^{2,7,29}$ Gold nanoparticles in the ablated material produce spikes across the Au concentration profile which looks like a saw-tooth pattern. However, two uniform SIMS profiles and one smooth LA-ICP-MS profile have been observed in the compositional field of nanoparticulate Au. The SIMS analyses were performed on two As-rich pyrite 
from a Carlin-type deposit (Goldstrike, Nevada), one containing $0.52 \mathrm{wt} \% \mathrm{Au}$ and $11.97 \mathrm{wt} \% \mathrm{As}$ $\left([\mathrm{Au}]_{\mathrm{at} .} /[\mathrm{As}]_{\mathrm{at} .}=0.017\right)$ and another containing $375 \mu \mathrm{g} / \mathrm{g}$ Au and $0.2 \mathrm{wt} \% \mathrm{As}\left([\mathrm{Au}]_{\mathrm{at} .} /[\mathrm{As}]_{\mathrm{at} .}=0.11\right){ }^{8}$ and the LA-ICP-MS analysis was performed on an As-depleted pyrite from the Huangtuliang gold deposit containing $157 \mu \mathrm{g} / \mathrm{g} \mathrm{Au}$ and $2.8 \mu \mathrm{g} / \mathrm{g} \mathrm{As} .{ }^{29}$ In these pyrite specimens, Au occurs, at least partly, in the crystal structure. Thus, As is not essential for Au to be bound chemically in the $\mathrm{FeS}_{2}$ framework. The non-arsenian Au species present in low As pyrite may very well occur and coexist with an As-bound species in As-rich pyrite. A mixture of As-bound and As-unbound Au species perhaps is the explanation to the absence or poor correlation between the Au and As contents observed in the $[\mathrm{Au}]_{\mathrm{at} .} /[\mathrm{As}]_{\mathrm{at} .}<0.02$ compositional field of some arsenian pyrite. ${ }^{5,28}$ Answer to this question and to the diversity of geochemical observations, some apparently contradictory, lies in structural studies on the oxidation state and bonding environment of $\mathrm{Au}$ in pyrite.

The most accepted formal oxidation state for $\mathrm{Au}$ in arsenian pyrite is $1+,{ }^{5}$ as determined by XANES in natural arsenian pyrite ${ }^{5}$ and HR-XANES in synthetic As-free pyrite. ${ }^{30,31}$ An oxidation state of 3+ was suggested in arsenian pyrite based on charge balance consideration using microprobe data, ${ }^{18,25}$ and also 1 - was proposed using X-ray photoelectron spectroscopy (XPS) analysis. ${ }^{32}$ The substitution mechanism proposed for each oxidation state is: (1) $\mathrm{Au}^{1+}$ for $\mathrm{Fe}$ substitution, ${ }^{5,}{ }^{33}$ (2) incorporation of (poly)sulfide clusters composed of $\mathrm{S}-\mathrm{Au}^{1+}-\mathrm{S}$ linear units, ${ }^{31}$ (3) $\mathrm{Au}^{3+}$ for $\mathrm{Fe}^{2+}$ substitution coupled with an $\mathrm{As}^{1-}$ for $\mathrm{S}^{2-}$ substitution, ${ }^{25}$ (4) coupled substitution of $\mathrm{Au}^{3+}$ and $\mathrm{Cu}^{+}$for two $\mathrm{Fe}^{2+},{ }^{18}$ and (5) $\mathrm{Au}^{1-}$ for $\mathrm{S}^{1-}$ substitution. ${ }^{32}$ In some studies, the hypothetical $\mathrm{Au}^{1+}$ for $\mathrm{Fe}$ substitution is backed up by a negative correlation between the concentrations of Au and Fe. ${ }^{74}$ In other studies, this correlation was not discerned for unclear reasons. ${ }^{10,33}$ The steric compatibility of $\mathrm{Au}^{1+}$ at the $\mathrm{Fe}^{2+}$ site is also not totally resolved. $\mathrm{Au}^{1+}$ has an ionic radius of $1.37 \AA$ and low-spin $\mathrm{Fe}^{2+}$ of $0.61 \AA .{ }^{35}$ On the basis of this metrical parameter, $\mathrm{Au}^{1+}$ is unlikely to enter the Fe site unless the site is highly distorted locally. ${ }^{2,4,33}$ However, the Fe-S and Au-S bonds have a covalent character, ${ }^{16}$ and the covalent radii of $\mathrm{Au}$ and low-spin Fe differ by only $1.36-1.32=0.04 \AA$. Incorporation of $\mathrm{Au}^{1+}$ at the $\mathrm{Fe}$ site has been demonstrated for synthetic As-free pyrite using HR-EXAFS spectroscopy. ${ }^{30}$ The Au-S bond length was $0.14 \AA$ longer than the Fe-S bond length, which corresponds to an expansion of $0.14 \AA / 2.26 \AA^{36}=6 \%$.

Three possible oxidation states also were suggested for Au in arsenopyrite: $1+$ using XANES, ${ }^{16}$, ${ }^{30} 3+$ based on charge balance, ${ }^{37}$ and 1- using XPS. ${ }^{32}$ The two last assignments are from earlier studies and have been discussed critically by Cabri et al. ${ }^{16}$ To date it is established that $\mathrm{Au}$ is formally monovalent and probably substitutional since it correlates inversely with Fe. ${ }^{10,27,28}$ 
Despite extensive study, the key question of the atomic-scale structure of chemically-bound $\mathrm{Au}$ and its relationship with the broad $\mathrm{Au}$-As geochemical correlation remains. Progress has lagged because of the difficulty of measuring $\mathrm{Au} \mathrm{L}_{3}$-edge EXAFS spectra in an Fe-rich matrix and the proximity of the Au L $\alpha$ and As K $\alpha$ emission lines in fluorescence-yield EXAFS measurement. Here, quality HR-XANES and HR-EXAFS spectra were obtained using a newly developed wavelengthdispersive X-ray spectrometer equipped with five high-luminosity crystals of $0.5 \mathrm{~m}$ bending radius. ${ }^{38}$ Micro HR-XANES and HR-EXAFS spectra of a pyrite and an arsenopyrite grain were measured on two selected points-of-interest from microfluorescence maps (HR-SXRF). The pyrite spot contained $0.48 \mathrm{wt} \% \mathrm{Au}$ and $1.31 \mathrm{wt} \% \mathrm{As}\left([\mathrm{Au}]_{\mathrm{at} .} /[\mathrm{As}]_{\mathrm{at} .}=0.14\right)$ and the arsenopyrite spot $0.84 \mathrm{wt} \% \mathrm{Au}$ and $44.6 \mathrm{wt} \%$ As $\left([\mathrm{Au}]_{\mathrm{at} t} /[\mathrm{As}]_{\mathrm{at} .}=7.1 \times 10^{-3}\right)$. The two ores had been characterized previously by conventional electron microscopy, SIMS, and ${ }^{197}$ Au Mössbauer spectroscopy. ${ }^{1,10,11,39,40}$

\section{MATERIALS AND METHODS}

The pyrite is from a refractory gold ore collected on a sandy mine tailing in Colombia, South America. The ore is composed dominantly of pyrite (90\%) and minor quartz, and has no arsenopyrite. The arsenopyrite comes from the Villeranges deposit located along the Marche Combrailles shear zones in the northwest of the French Massif Central. The ore is hosted by Visean volcano-sedimentary tuffs which were intensely fractured 300-315 Ma ago favoring hydrothermal circulation along the shear zones. Gold-rich arsenopyrite occurs in quartz and ankerite veinlets and also as isolated crystals in the tuffs. Ore fluids were aqueous, with low salinity and a temperature between 160 and $200{ }^{\circ} \mathrm{C}$. The host rocks were totally transformed in quartz-illite, indicating that the syn-ore fluids had a low $\mathrm{pH}$ with a $f_{\mathrm{O} 2}$ between the hematite- magnetite and $\mathrm{Ni}-\mathrm{NiO}$ redox buffers. ${ }^{11}$

A polished section of each ore was analyzed by EPMA and chemical mapping, and afterward by synchrotron-based X-ray micro-fluorescence (HR-SXRF) to relocate the regions of interest for micro Au L L $_{3}$-edge HR-XANES and HR-EXAFS analysis (Figures S1 and S2). Laterally resolved measurements were performed on the microprobe endstation of beamline BM23 at the European Synchrotron Radiation Facility (ESRF, Grenoble). The flux incident on the sample $\left(I_{0}\right)$ was $4.5 \times 10^{9}$ photons/sec in a spot size of $4 x 4 \mu \mathrm{m}^{2}$. Bulk HR-XANES of a fine powder from the arsenopyrite ore and reference spectra were measured on beamline ID26 of the ESRF. The flux incident on the sample $\left(I_{0}\right)$ was $10^{13}$ photons/sec in a spot size of $0.08(\mathrm{~V}) \times 0.7(\mathrm{H}) \mathrm{mm}^{2}$. The BM23 and ID26 data were intercalibrated on the same energy scale taking the maximum of the first derivative of a thin Au foil at $11919.0 \mathrm{eV}$. Additional methodological information is provided in the Supporting Information (SI). 
$\mathrm{Au} \mathrm{L}_{3}$-edge XANES spectra were calculated ab initio with the finite difference method (FDM) as implemented in FDMNES. ${ }^{41}$ The code calculates the final state potential in real space from a cluster of atoms. The form of the potential is not approximated, in contrast to the alternative muffin-tin approach, ${ }^{42,} 43$ thus providing a better description of scattering phenomena. FDM-FDMNES calculation also provides the partial density of states (DOS) of the X-ray absorbing atom (i.e., Au) resolved over the $(l, m)$ quantum numbers.

A photograph of the 0.5 meter X-ray emission spectrometer installed on BM23 is shown in Figure 1a. Its capability is illustrated in Figures $1 \mathrm{~b}$ and $1 \mathrm{c}$ with the micro X-ray fluorescence spectra of the $\mathrm{Au}$ spots for pyrite and arsenopyrite analyzed by HR-XANES/EXAFS. At $[\mathrm{Au}]_{\mathrm{at}} /[\mathrm{As}]_{\mathrm{at}}=0.14$ (arsenian pyrite), the Au L $\alpha$ fluorescence line $(9713 \mathrm{eV})$ is extremely weak in total florescence-yield (TFY) hampering the collection of useful X-ray absorption data. At $[\mathrm{Au}]_{\mathrm{at}} /[\mathrm{As}]_{\mathrm{at}}=7.1 \times 10^{-3}$ (arsenopyrite), the Au L $\alpha$ fluorescence line is totally shadowed by the low energy tail of the As K $\alpha$ fluorescence line (10543 eV). Gold is invisible in TFY detection mode. The parasitic As Ka line is eliminated (pyrite) or drastically attenuated (arsenopyrite) like other unwanted lines at high energyresolution using a crystal multi-analyzer. The spectrometer was set to the fixed energy of the Au L $\alpha_{1}$ line and the fluorescence spectra were recorded with a silicon-drift (SDD) detector. In this mode, the $\mathrm{Au} \mathrm{L} \alpha_{1}$ fluorescence is Bragg reflected by the spectrometer crystals whereas fluorescence lines at all other energies reach the detector via weak scattering events. In addition, the close proximity of the As K-edge to the $\mathrm{Au} \mathrm{L}$-edge makes it difficult to measure high quality Au spectra in fluorescenceyield mode (Figure 1d). The As background in the Au spectrum is eliminated with analyzer crystals, allowing measurement of nearly pure $\mathrm{Au} L \alpha_{1}$ fluorescence. Figure $1 \mathrm{~d}$ also illustrates how the spectral features in the absorption edge are better resolved by tuning the Bragg angle of the spectrometer to the $\mathrm{Au} \mathrm{L} \alpha_{1}$ line. The physical origin of this sharpening effect has been described previously. ${ }^{44}$

\section{RESULTS AND DISCUSSION}

Concentration and distribution of $\mathrm{Au}$. $\mathrm{Au}$ is distributed irregularly in growth zones of the pyrite and arsenopyrite grains (Figures $2 \mathrm{a}$ and $2 \mathrm{~b}$ ). A total of 38 EPMA analyses were performed on pyrite and 26 on arsenopyrite (Tables S1 and S2). The chemical formulae, calculated to the nonstoichiometric compositions $(\mathrm{Fe}, \mathrm{Au}, \mathrm{Cu}, \square) \mathrm{S}_{2-x} \mathrm{As}_{x}$ for pyrite and $(\mathrm{Fe}, \mathrm{Au}, \mathrm{Cu}, \square) \mathrm{As}_{1-x} \mathrm{~S}_{1+x}$ for arsenopyrite where $\square$ is a cation vacancy, are $(\mathrm{Fe}, \mathrm{Cu}, \mathrm{Au}) \mathrm{S}_{2-x} \mathrm{As}_{x}$ with $0.00 \leq x \leq 0.03$ for pyrite and $(\mathrm{Fe}, \mathrm{Cu}, \mathrm{Au}) \mathrm{As}_{1-x} \mathrm{~S}_{1+x}$ with $0.01 \leq x \leq 0.10$ for arsenopyrite (Tables S3 and S4). All cationic sites are occupied, there are no octahedral vacancies (Figures $3 \mathrm{a}$ and $3 \mathrm{~b}$ ). 
In pyrite, the $\mathrm{Au}$ and $\mathrm{As}$ concentration ranges are $0.004 \mathrm{wt} \% \leq \mathrm{Au} \leq 0.48 \mathrm{wt} \%$ and $0.15 \mathrm{wt} \% \leq$ As $\leq 1.9 \mathrm{wt} \%$. There is no correlation between the Au and As contents (Figure 3c), in agreement with previous analyses of the Colombian ore. ${ }^{10}$ Twenty six analyses plot above the solubility limit representing nanoparticulate $\mathrm{Au}^{0}$ according to Reich et al. ${ }^{7}$. The arsenopyrite grain contains two compositional populations of $\mathrm{Au}$ : a low-Au population located in depleted growth zones containing 0.057-0.21 wt \% Au, and a high-Au population containing 0.62-0.88 wt\% Au (Figures 3b and 3d). The maximum concentration is below the $2 \%$ limit inferred by Reich and coworkers. ${ }^{7}$ The Au-rich regions are richer in As $\left(r=0.78, p=2.610^{-6}\right)$, which suggests that $\mathrm{Au}$ is bonded predominantly to As over $\mathrm{S}$ in the structure of arsenopyrite. In contrast, the absence of Au-As correlation in the pyrite grain suggests a Au-S bonding. No gold particles were discerned in either grain, although metallic gold occurs in the Colombia ore. ${ }^{10}$ Therefore, all gold appears to be chemically-bound in the two sulfides on a micron size scale.

Oxidation state of Au. Micro HR-XANES spectra of pyrite and arsenopyrite collected from the Au-rich spots shown in Figures $4 \mathrm{a}$ and $4 \mathrm{~b}$ are plotted in Figure 5a along with reference spectra. A bulk HR-XANES spectrum of arsenopyrite also was recorded in order to verify that the point measurement truly represents all of what is found in the entire sample and to dismiss the presence of gold nanonuggets (data not shown). The data are consistent with those reported in Trigub et al. ${ }^{30}$ on synthetic auriferous sulfides. The sulfide spectra are shifted to higher energy relative to the two $\mathrm{Au}(\mathrm{III})$ references $\mathrm{AuCl}_{3}$ and $\mathrm{Au}_{2} \mathrm{O}_{3}$, which shows that $\mathrm{Au}$ is nominally monovalent in pyrite and arsenopyrite (Figure 5a). The energy position of the white lines are $11921.3 \mathrm{eV}$ for pyrite, 11921.9 $\mathrm{eV}$ for arsenopyrite, and $11922.2 \mathrm{eV}$ for $\mathrm{Au}_{2} \mathrm{~S}$, compared to $11920.2 \mathrm{eV}$ and $11920.3 \mathrm{eV} \mathrm{for} \mathrm{Au}_{2} \mathrm{O}_{3}$ and $\mathrm{AuCl}_{3}$. The $0.6 \mathrm{eV}$ difference in energy between pyrite and arsenopyrite is interpreted as an electronegativity effect of the donor ligands. We showed previously with a FDM-FDMNES calculation that the XANES spectrum of $\mathrm{Au}^{1+}$ shifts to lower energy when $\mathrm{Au}$ is bonded to $\mathrm{Cl}$ (electronegativity $=3.16$ ) relative to $S$ (electronegativity $=2.58$ ) (Figure 8 of Ref. ${ }^{45}$ ). With an electronegativity of 2.18, As is predicted to shift the Au-XANES spectrum up in energy, which we verified with a FDM-FDMNES calculation.

Replacing the $6 \mathrm{~S}$ ligands with 6 As in the coordination sphere of Au in pyrite shifts the edge maximum rightward by about $1 \mathrm{eV}$ (Figure 5b). The same ligand effect is observed for arsenopyrite between the $\mathrm{AuS}_{6}$ and $\mathrm{Au}\left(\mathrm{S}_{3} \mathrm{As}_{3}\right)$ coordinations $(\Delta \mathrm{E}=0.3 \mathrm{eV})$, and between the $\mathrm{Au}\left(\mathrm{S}_{3} \mathrm{As}_{3}\right)$ and $\mathrm{AuAs} 6$ coordinations $(\Delta \mathrm{E}=1 \mathrm{eV})$. The sensitivity of XANES to the nature of the $\mathrm{Au}^{1+}$ ligand can be 
understood in terms of the energetics of the empty density of states (DOS) for Au and its donor ligands. The $\mathrm{Au} \mathrm{L}_{3} \mathrm{X}$-ray absorption edge corresponds to the dipole-allowed $2 \mathrm{p}_{3 / 2} \rightarrow 6 \mathrm{~s} 5 \mathrm{~d}$ transition of $\mathrm{Au}$, which in $\sigma$-bonding with polarizing ligands has the electronic configuration $[\mathrm{Xe}] 4 \mathrm{f}^{14} 6 \mathrm{~s}^{1-x} 5 \mathrm{~d}^{10-}$ ${ }^{y}$ and its $6 \mathrm{~s}^{1-x} 5 \mathrm{~d}^{10-y}$ valence orbitals hybridized with the S $3 \mathrm{sp}$ and As $4 \mathrm{sp}$ orbitals. ${ }^{45}$ Figure 6 shows the d-DOS of Au together with the p-DOS of S and As. The s orbitals are not shown because the amplitude of the $2 \mathrm{p}_{3 / 2} \rightarrow 6 \mathrm{~s}^{1-x}$ transition is much smaller than the amplitude of the $2 \mathrm{p}_{3 / 2} \rightarrow 5 \mathrm{~d}^{1-y}$ transition. As expected from dipole selection rules, it is seen that all absorption features in the calculated spectra correlate with the intensity of the Au d-DOS. The profiles of the Au d-DOS and $\mathrm{S} /$ As p-DOS overlap as a result of the $\sigma$-bonding, and move to higher energy when $6 \mathrm{~S}$ ligands are replaced with 6 As ligands in both pyrite and arsenopyrite. Therefore, the experimental edge shift between the pyrite and arsenopyrite spectra (Figure 5a) suggests a Au-S bonding in pyrite and a AuAs bonding in arsenopyrite. Also, the high experimental amplitude of the Au edge suggests that Au is octahedrally coordinated because the strength of the $2 \mathrm{p}_{3 / 2} \rightarrow 5 \mathrm{~d}^{1-y}$ transition is proportional to the density of holes in the $5 \mathrm{~d}$ orbitals ( $y$ value), which itself increases with the number of ligands due to orbital hybridization. This effect is seen in Figure 5a with the $\mathrm{Au}_{2} \mathrm{~S}$ reference, in which $\mathrm{Au}$ is coordinated linearly to two $\mathrm{S}$ atoms. The edge amplitude of $\mathrm{Au}_{2} \mathrm{~S}$ is considerably reduced with regard to that of the two Fe sulfides. We conclude that Au substitutes for Fe in pyrite and arsenopyrite. The linear S-Au-S coordination described recently in synthetic pyrite using the $\mathrm{Au}_{2} \mathrm{~S}$ reference ${ }^{31}$ is an incompatible model for the two natural gold sulfides studied here.

Local structure of Au. The micro HR-EXAFS spectra of pyrite and arsenopyrite collected from Au-rich spots are clearly distinct between $k=3$ and $9 \AA^{-1}$ (Figure 7a). The shift of the two $\chi(k)$ frequencies is manifested in the radial distribution function obtained by Fourier transformation as a shift to higher distance and a higher amplitude of the first peak for arsenopyrite and also the absence of second peak at $R+\Delta R=3.2 \AA$ (Figure 7b). A difference of local structure around the Au atoms is expected since $\mathrm{FeS}_{2}$ and FeAsS do not have the same crystallographic structure (Figure 8). The first peak corresponds to the contribution from the coordination shell, and the difference in amplitude and peak position suggest a bonding to lighter and smaller $\mathrm{S}$ atoms in pyrite and to heavier and larger As atoms in arsenopyrite. The second and third atomic shells around Au are better distinguished by Fourier filtering their contribution to the total EXAFS signal in the $2.8 \AA<R+\Delta R<4.0 \AA$ interval (Fig. 7c). The pyrite wave has a beating node at $k=10 \AA^{-1}$, suggesting that two atomic shells should 
suffice to fit the data. The arsenopyrite wave has a different envelope, no beat pattern, and is damped, likely due to greater structural disorder.

The spectrum of pyrite was fit with $5.7 \pm 0.7 \mathrm{~S}$ atoms at $2.41 \AA, 7.6 \pm 1.4 \mathrm{~S}$ at $3.50 \AA$ and $11.9 \pm$ 3.7 Fe atoms at $3.85 \AA$ (Figure 9a, Table 1). The data could not be fit with a second shell of As atoms. This does not preclude some As atoms from being present at around $3.50 \AA$. The Au-S bond length is $0.15 \AA$ longer than the Fe-S bond length of pyrite, whereas the second and third nearest shell distances around $\mathrm{Au}$ are similar to those around $\mathrm{Fe}$ in pyrite (Table 1). Thus, the structural relaxation appears limited to the first atomic shell. Ab initio modeling of the Au-pyrite structure using CRYSTAL14 ${ }^{46}$ shows that insertion of the larger Au atom is accommodated locally by a modification of the interpolyhedral angles between the corner linked octahedra (i.e., compliance effect) (Table 1 and SI). A similar observation was reported for the incorporation of trace elements in calcite, in which the compliance of the Ca site to substitutional impurities was attributed to the corner sharing topology of the carbonate structure. ${ }^{47}$ The lack of As around $\mathrm{Au}$ at the atomic scale provides an explanation for the absence of Au-As correlation at the macroscopic scale (Figure 3a).

The first shell around $\mathrm{Au}$ in arsenopyrite was fit with $5.6 \pm 0.3$ As atoms at $2.52 \AA$, to be compared with the crystallographic values of $3 \mathrm{~S}$ at $2.23 \AA$ and 3 As at 2.37-2.41 $\mathrm{A}$ around Fe (Table 1). The expansion of the Au-As distance (0.11-0.15 $\AA$ ) is close in value to that observed in pyrite $(0.15 \AA)$ and to those predicted by DFT $(0.10-0.08 \AA$, Table 1$)$. The AuAs 6 coordination revealed by EXAFS is consistent with the Au-As correlation observed by EPMA (Figure 3d), and with the shift to higher energy of the XANES spectrum (Figure 5a). Analysis of the second and third shell is less conclusive. The data can be fit equally well with $4.3 \pm 0.3 \mathrm{~S}$ at $3.73 \AA$ and $3.7 \pm 0.3$ As at $3.94 \AA$ (model 1), and $8 \mathrm{~S}$ at $3.77 \AA$ and $4 \mathrm{Fe}$ at $4.00 \AA$ (model 2) (Figures $9 \mathrm{~b}$ and 9c). Model 1 has the same number of $\mathrm{S}$ and As atoms as stoichiometric FeAsS $(\mathrm{CN}(\mathrm{S})+\mathrm{CN}(\mathrm{As})=8$, Table 1). Under this scheme, three As atoms are added to the structure per Au and the chemical environment of the metal site beyond the AuAs 6 octahedron is conserved. The new chemical formula can be written $\left(\mathrm{Fe}_{1-}\right.$ $\left.{ }_{x} \mathrm{Au}_{\mathrm{x}}\right) \mathrm{As}_{1+3 \mathrm{x}} \mathrm{S}_{1-3 \mathrm{x}}$. Model 2 has no As in the second shell. This model has for ideal formula $\left(\mathrm{Fe}_{1-}\right.$ $\left.{ }_{x} \mathrm{Au}_{\mathrm{x}}\right) \mathrm{AsS}$. Under this scheme, the AuAs 6 coordination is obtained by displacing three As from the second shell to the first shell. Only model 1 appears compatible with the positive correlation between $\mathrm{Au}$ and As. The limit of the number of free parameters in the fits, as calculated by the Nyquist formula $N=(2 \Delta R \Delta k) / \pi$, was not exceeded in any of the cases indicating that the EXAFS parameters are robust. Nine parameters were adjusted at most (Table 1), for a number of degrees of freedom in the refinements of $N=\left[\left(2 \times\left(13.3-3.7 \AA^{-1}\right) \times(4.0-1.5 \AA)\right] / \pi=15.3\right.$. Simulation involving Au-Au pairs 
in the third shell of pyrite to test a clustering of Au resulted in 50\% increase of the fit residual (Figure $\mathrm{S} 3 \mathrm{a}$, Table S5). EXAFS data are also incompatible with the inclusion of $\mathrm{AuS}_{2}$ clusters and isomorphous aurostibite-like clusters $\left(\mathrm{AuSb}_{2}\right)$ (Figures $\mathrm{S} 3 \mathrm{~b}$ and $\mathrm{S} 3 \mathrm{c}$ ).

According to model 1, the plot of [As] against [Au] should have a slope of 3 since three As atoms are added to the structure per $\mathrm{Au}$. The $[\mathrm{Au}]$ against $[\mathrm{As}]$ plot of Figure $3 \mathrm{~d}$ has a slope of 0.082 , corresponding to an $[\mathrm{As}] /[\mathrm{Au}]$ ratio of $1 / 0.08=12$ instead of 3 . Au-As correlations have even lower slopes in previous studies, from 0.05 down to $0.01-0.02 .^{10,16}$ It follows that one Au atom is incorporated in the arsenopyrite structure for at least twelve As atoms. If all As for S substitutions occur around the $\mathrm{Au}$ site, the $\mathrm{AuAs}_{12}$ cluster will be $5.4 \AA$ in size. This arrangement is crystallographically possible since the mineral $\mathrm{FeAs}_{2}$, named löllingite, is isostructural with FeAsS. ${ }^{48}$ The AuAs12 cluster with an FeAs2-type structure would be inclosed in the FeAsS framework. Although structurally feasible, the occurrence of intergrown $\mathrm{AuAs}_{n}$ clusters in arsenopyrite is negated by EXAFS because Au has an FeAsS-type short-range order beyond the first atomic shell. According to Fleet and coworkers ${ }^{4} \mathrm{Au}$ is removed from ore fluids by chemisorption at As-rich, Fe-deficient surface sites in the Fe-As-S system and incorporated in the solid phase as a metastable solid solution. The AuAs 6 coordination may result from the chemisorption of gold-arsenide complex on As-exposed, Fe-deficient growth surface sites of arsenopyrite, and the $\mathrm{AuS}_{6}$ coordination from the chemisorption of $\mathrm{AuHS}^{0}$ and $\mathrm{Au}(\mathrm{HS})_{2}{ }^{-}$complex ${ }^{31,49-55}$ on $\mathrm{S}$, Fe-deficient growth surface sites of arsenian pyrite. If this interpretation is correct, then the anomalous As content of auriferous sulfide ores and the As-Au correlation may reside, among other factors, in the high arsenic content of the mineralizing fluids and the chemical affinity of $\mathrm{Au}$ for As in arsenian sulfide fluids. The AuAs6 coordination perhaps is a relic of the Au-As complex that existed in aqueous hydrothermal solutions. When the hydrothermal fluids are depleted in $\mathrm{As}$, then $\mathrm{Au}$ forms a $\mathrm{AuS}_{6}$ surface complex at the surface of pyrite, later buried in As-depleted zones of the mineral structure. Conditions under which two different zones of arsenopyrite were formed were different in terms of sulfur and arsenic fugacity, and perhaps also temperature.

\section{CONCLUSION}

The coupled substitution of $\mathrm{Au}$ and As at the octahedral $\mathrm{Fe}(\mathrm{As}, \mathrm{S})_{6}$ site of arsenopyrite is the most important new insight from this study. A strong correlation between the concentrations of Au and As is probably a geochemical signature for a AuAs6 coordination at the atomic-scale. In reverse, absence of $\mathrm{Au}$-As correlation in pyrite is probably a signature for a $\mathrm{AuS}_{6}$ coordination. A weak geochemical 
correlation of $\mathrm{Au}$ and $\mathrm{As}$ may indicate the existence of $\mathrm{AuAs}_{5} \mathrm{~S}$ and $\mathrm{AuAs} 4 \mathrm{~S}_{2}$ coordinations or the coexistence of the AuAs 6 and $\mathrm{AuS}_{6}$ coordinations in the analyzed sample. The pyrite grain analyzed here is not representative of all arsenian pyrite described in the literature. A Au-As geochemical association often is observed, but these arsenian pyrite are more arduous to study by X-ray absorption spectroscopy because they are much richer in As. The study of pyrite and arsenopyrite grains from other sources and differing in Au-As correlation will no doubt shed more light on the chemical forms of "invisible" gold in sulfide deposits.

\section{ASSOCIATED CONTENT}

\section{Supporting Information}

The Supporting Information is available free of charge on the ACS Publications website at DOI:

Supplementary methods (EPMA, SXRF, XANES, EXAFS, DFT calculations), EPMA analyses (Tables S1 to S4), HR-SXRF maps of polished sections (Figures S1 and S2), EXAFS fits (Table S5 and Figure S3), Cartesian coordinates of the Au-substituted pyrite and arsenopyrite models.

\section{Cover Illustration}

A Cover Illustration is available at DOI: XX

\section{AUTHOR INFORMATION}

Corresponding Authors

*E-mail: margarit.merkulova@gmail.com

*E-mail: alain.manceau@univ-grenoble-alpes.fr

\section{ORCID}

Alain Manceau: 0000-0003-0845-611X

Pieter Glatzel: 0000-0001-6532-8144

\section{Notes}

The authors declare no competing financial interest.

\section{ACKNOWLEDGMENTS}


The $\mathrm{Au}_{2} \mathrm{~S}$ reference was provided by Gleb Pokrovski. We thank two anonymous reviewers for helpful and constructive comments. The study was funded by ANR under Grant No. ANR-10-EQPX-27-01 (EcoX Equipex).

\section{REFERENCES}

(1) Cathelineau, M.; Boiron, M. C.; Holliger, P.; Marion, P.; Denis, M., Gold in arsenopyrites: crystal chemistry, location and state, physical chemical conditions of deposition. In The Geology of Gold deposits : The Perspective in 1988, Econ. Geol. Monograph 6, 1989; pp 328-340.

(2) Cook, N. J.; Chryssoulis, S. L., Concentrations of "Invisible Gold" in the common sulfides. Can. Miner. 1990, 28, 1-16.

(3) Fleet, M. E.; Chryssoulis, S. L.; Maclean, P. J.; Davidson, R.; Weisener, C. G., Arsenian pyrite from gold deposits - Au and As distribution investigated by SIMS and EMP, and color staining and surface oxidation by XPS and LIMS. Can. Miner. 1993, 31, 1-17.

(4) Fleet, M. E.; Mumin, A. H., Gold-bearing arsenian pyrite and marcasite and arsenopyrite from Carlin Trend gold deposits and laboratory synthesis. Am. Miner. 1997, 82, 182-193.

(5) Simon, G.; Huang, H.; Penner-Hahn, J. E.; Kesler, S. E.; Kao, L. S., Oxidation state of gold and arsenic in gold-bearing arsenian pyrite. Am. Miner. 1999, 84, 1071-1079.

(6) Palenik, C. S.; Utsunomiya, S.; Reich, M.; Kesler, S. E.; Wang, L.; Ewing, R. C., "Invisible" gold revealed: Direct imaging of gold nanoparticles in a Carlin-type deposit. Am. Miner. 2004, 89, 1359-1366.

(7) Reich, M.; Kesler, S. E.; Utsunomiya, S.; Palenik, C. S.; Chryssoulis, S. L.; Ewing, R. C., Solubility of gold in arsenian pyrite. Geochim. Cosmochim. Acta 2005, 69, 2781-2796.

(8) Paktunc, D.; Kingston, D.; Pratt, A.; McMullen, J., Distribution of gold in pyrite and in products of its transformation resulting from roasting of refractory gold ore. Can. Miner. 2006, 44, 213-227.

(9) Large, R. R.; Danyushevsky, L.; Hollit, C.; Maslennikov, V.; Meffre, S.; Gilbert, S.; Bull, S.; Scott, R., et al., Gold and trace element zonation in pyrite using a laser imaging technique: Implications for the timing of gold in orogenic and carlin-style sediment-hosted deposits. Econ. Geol. 2009, 104, 635-668.

(10) Benzaazoua, M.; Marion, P.; Robaut, F.; Pinto, A., Gold-bearing arsenopyrite and pyrite in refractory ores: analytical refinements and new understanding of gold mineralogy. Miner. Mag. 2007, 71, 123-142.

(11) Boiron, M. C.; Cathelineau, M.; Trescases, J. J., Conditions of gold-Bearing arsenopyrite crystallization in the Villeranges Basin, Marche-Combrailles shear zone, France: A mineralogical and fluid inclusion study. Econ. Geol. 1989, 84, 1340-1362.

(12) Bakken, B. M.; Hochella, M. F.; Marshall, A. F.; Turner, A. M., High-resolution microscopy of gold in unoxidized ore from the Carlin mine, Nevada. Econ. Geol. 1989, 84, 171-179.

(13) Mumin, A. H.; Fleet, M. E.; Chryssoulis, S. L., Gold minealization in As-rich mesothermal gold ores of the Bogosu-Prestea mining district of the Ashanti Gold Belt, Ghana: remobilization of "invisible" gold. Miner. Deposita 1994, 29, 445-460.

(14) Genkin, A. D.; Bortnikov, N. S.; Cabri, L. J.; Wagner, F. E.; Stanley, C. J.; Safonov, Y. G.; Mcmahon, G.; Friedl, J., et al., A multidisciplinary study of invisible gold in arsenopyrite from four mesothermal gold deposits in Siberia, Russian Federation. Econ. Geol. 1998, 93, 463-487. 
(15) Yang, S.; Blum, N.; Rahders, E.; Zhang, Z., The nature of invisible gold in sulfides from the Xiangxi Au-Sb-W ore deposit in northwestern Hunan, People's Republic of China. Can. Miner. 1998, $36,1361-1372$.

(16) Cabri, L. J.; Newville, M.; Gordon, R. A.; Crozier, E. D.; Sutton, S. R.; McMahon, G.; Jiang, D. T., Chemical speciation of gold in arsenopyrite. Can. Miner. 2000, 38, 1265-1281.

(17) Pals, D. W.; Spry, P. G.; Chryssouls, S., Invisible gold and tellurium in arsenic-rich pyrite from the Emperor gold deposit, Fiji: Implications for gold distribution and deposition. Econ. Geol. 2003, 98, 479-493.

(18) Chouinard, A.; Paquette, J.; Williams-Jones, A. E., Crystallographic controls on trace-element incorporation in Auriferous pyrite from the Pascua epithermal high-sulfidation deposit, ChileArgentina. Can. Miner. 2005, 43, 951-963.

(19) Morey, A. A.; Tomkins, A. G.; Bierlein, F. P.; Weinberg, R. F.; Davidson, G. J., Bimodal distribution of gold in pyrite and arsenopyrite: Examples from the Archean Boorara and Bardoc shear systems, Yilgarn craton, Western Australia. Econ. Geol. 2008, 103, 599-614.

(20) Sung, Y. H.; Brugger, J.; Ciobanu, C. L.; Pring, A.; Skinner, W.; Nugus, M., Invisible gold in arsenian pyrite and arsenopyrite from a multistage Archaean gold deposit: Sunrise Dam, Eastern Goldfields Province, Western Australia. Miner. Deposita 2009, 44, 765-791.

(21) Majzlan, J.; Chovan, M.; Andras, P.; Newville, M.; Wiedenbeck, M., The nanoparticulate nature of invisible gold in arsenopyrite from Pezinok (Slovakia). Neues Jb. Miner. Abh. 2010, 187, $1-9$.

(22) Cook, N. J.; Ciobanu, C. L.; Meria, D.; Silcock, D.; Wade, B., Arsenopyrite-pyrite association in an orogenic gold ore: Tracing mineralization history from textures and trace elements. Econ. Geol. 2013, 108, 1273-1283.

(23) Deditius, A. P.; Reich, M.; Kesler, S. E.; Utsunomiya, S.; Chryssoulis, S. L.; Walshe, J.; Ewing, R. C., The coupled geochemistry of Au and As in pyrite from hydrothermal ore deposits. Geochim. Cosmochim. Acta 2014, 140, 644-670.

(24) Fougerouse, D.; Reddy, S. M.; Saxey, D. W.; Rickard, W. D. A.; Van Riessen, A.; Micklethwaite, S., Nanoscale gold clusters in arsenopyrite controlled by growth rate not concentration: Evidence from atom probe microscopy. Am. Miner. 2016, 101, 1916-1919.

(25) Arehart, G. B.; Chryssoulis, S. L.; Kesler, S. E., Gold and arsenic in iron sulfides from sediment hosted disseminated gold deposits: Implication for depositional processes. Econ. Geol. 1993, $88,171-185$.

(26) Deditius, A. P.; Utsunomiya, S.; Renock, D.; Ewing, R. C.; Ramana, C. V.; Becker, U.; Kesler, S. E., A proposed new type of arsenian pyrite: Composition, nanostructure and geological significance. Geochim. CosmochiM Acta 2008, 72, 2919-2933.

(27) Wu, X.; Delbove, F., Hydrothermal synthesis of gold-bearing arsenopyrite. Econ. Geol. 1989, 84, 2029-2032.

(28) McClenaghan, S. H.; Lentz, D. R.; Cabri, L. J., Abundance and speciation of gold in massive sulfides of the Bathurst Mining Camp, New Brunswick, Canada. Can. Miner. 2004, 42, 851-871.

(29) Cook, N. J.; Ciobanu, C. L.; Mao, J. W., Textural control on gold distribution in As-free pyrite from the Dongping, Huangtuliang and Hougou gold deposits, North China Craton (Hebei Province, China). Chem. Geol. 2009, 264, 101-121.

(30) Trigub, A. L.; Tagirov, B. R.; Kvashnina, K. O.; Chareev, A.; Nickolsky, M. S.; Shiryaev, A. A.; Baranova, N. N.; Kovalchuk, E. V., et al., X-ray spectroscopy study of the chemical state of "invisible"Au in synthetic minerals in the Fe-As-S system. Am. Miner. 2017, 102, 1057-1065.

(31) Pokrovski, G. S.; Kokha, M. A.; Proux, O.; Hazemann, J. L.; Bazarkina, E. F.; Testemale, D.; Escoda, C.; Boiron, M. C., et al., The nature and partitioning of invisible gold in the pyrite-fluid system. Ore Geol. Rev. 2019, 109, 545-563. 
(32) Li, J.; Feng, D.; Qi, F.; Zhang, G., The existence of the negative charge of gold in sulphide minerals and its formation mechanism. Acta Geol. Sinica - Eng. Ed. 1995, 8, 303-315.

(33) Simon, G.; Kesler, S. E.; Chryssoulis, S., Geochemistry and textures of gold-bearing arsenian pyrite, Twin Creeks, Nevada: Implications for deposition of gold in Carlin-type deposits. Econ. Geol. 1999, 94, 405-421.

(34) Tarnocai, C. A.; Hattori, K. H.; Cabri, L. J., Invisible gold in sulfides from the Campbell mine, Red Lake Greenstone Belt, Ontario: Evidence for mineralization during the peak of metamorphism. Can. Miner. 1997, 35, 805-815.

(35) Shannon, R. D., Revised effective ionic radius and systematic studies of interatomic distances in halides and chalcogenides. Acta Cryst. 1976, B25, 925-946.

(36) Rieder, M.; Crelling, J. C.; Šustai, O.; Drábek, M.; Weiss, Z.; Klementová, M., Arsenic in iron disulfides in a brown coal from the North Bohemian Basin, Czech Republic. Intern. J. Coal Geol. 2007, 71, 115-121.

(37) Johan, Z.; Marcoux, E.; Bonnemaison, M., Arsenopyrite aurifere: mode de substitution de Au dans la structure de FeAsS. C. R. French Acad. Sci. 1989, Serie 2, 185-191.

(38) Rovezzi, M.; Lapras, C.; Manceau, A.; Glatzel, P.; Verbeni, R., High energy-resolution x-ray spectroscopy at ultra-high dilution with spherically bent crystal analyzers of $0.5 \mathrm{~m}$ radius. Rev. Sci. Instrum. 2017, 88, 1-9.

(39) Marion, P.; Holliger, P.; Boiron, M. C.; Cathelineau, M.; Wagner, F. E., New improvements in the characterization of refractory gold in pyrites: an electron microprobe, Mössbauer spectrometry and ion microprobe study. Proceedings of Symposium "Brazil Gold '91", Bello Horizonte, Minas Gerais, Brazil 1991, 389-395.

(40) Friedl, J.; Wagner, F. E.; Sawick, J. A.; Harris, D. C.; Mandarino, J. A.; Marion, P., ${ }^{197}$ Au, ${ }^{57} \mathrm{Fe}$ and ${ }^{121} \mathrm{Sb}$ Mössbauer study of gold minerals and ores Hyperfine Interact. 1992, 70, 945-948.

(41) Joly, Y., X-ray absorption near-edge structure calculations beyond the muffin-tin approximation. Phys. Rev. B 2001, 63, n 125120.

(42) Ankudinov, A. L.; Rehr, J. J., Relativistic calculations of spin-dependent X-ray-absorption spectra. Phys. Rev. B 1997, 56, 1712-1716.

(43) Bunau, O.; Joly, Y., Self-consistent aspects of X-ray absorption calculations. J. Phys. Condens. Matter. 2009, 21, 345501.

(44) Glatzel, P.; Bergmann, U., High resolution 1s core hole X-ray spectroscopy in 3d transition metal complexes - electronic and structural information. Coord. Chem. Rev. 2005, 249, 65-95.

(45) Manceau, A.; Lemouchi, C.; Rovezzi, M.; Lanson, M.; Glatzel, P.; Nagy, K. L.; GautierLuneau, I.; Joly, Y., et al., Structure, bonding, and stability of mercury complexes with thiolate and thioether ligands from high-resolution XANES spectroscopy and first-principles calculations. Inorg. Chem. 2015, 54, 11776-11791.

(46) Dovesi, R.; Orlando, R.; Erba, A.; Zicovich-Wilson, C. M.; Civalleri, B.; Casassa, S.; Maschio, L.; Ferrabone, M., et al., CRYSTAL14: A Program for the ab initio investigation of crystalline solids. Intern. J. Quant. Chem. 2014, 114, 1287-1317.

(47) Reeder, R.; Lamble, G. M.; Northrup, P. A., XAFS study of the coodination and local relaxaton around $\mathrm{Co}^{2+}, \mathrm{Zn}^{2+}, \mathrm{Pb}^{2+}$, and $\mathrm{Ba}^{2+}$ trace elements in calcite. Am. Miner. 1999, 84, 10491060.

(48) Kjekshus, A.; Rakke, T.; Andresen, A. F., Compounds with the marcasite type crystal stucture. IX. Structural data for FeAs $2, \mathrm{FeSe}_{2}, \mathrm{NiAs}_{2}, \mathrm{NiSb}_{2}$, and $\mathrm{CuSe}_{2}$. Acta Chem. Scand. 1974, 28, 996-1000.

(49) Loucks, R. R.; Mavrogenes, J. A., Gold solubility in supercritical hydrothermal brines measured in synthetic fluid inclusions. Science 1999, 284, 2159-2163. 
(50) Seward, T. M., Thio complexes of gold and the transport of gold in hydrothermal ore solutions. Geochim. Cosmochim. Acta 1973, 37, 379-399.

(51) Pokrovski, G. S.; Akinfiev, N. N.; Borisova, A. Y.; Zotov, A. V.; Kouzmanov, K., Gold speciation and transport in geological fluids: insights from experiments and physical-chemical modelling. Geol. Soc. London Special Pub. 2014, 402, 9-70.

(52) Pokrovski, G. S.; Borisova, A. Y.; Harrichoury, J. C., The effect of sulfur on vapor-liquid fractionation of metals in hydrothermal systems. Earth Planet Sci. Lett. 2008, 266, 345-362.

(53) Pokrovski, G. S.; Kokh, M. A.; Guillaume, D.; Borisova, A. Y.; Gisquet, P.; Hazemann, J. L.; Lahera, E.; Del Net, W., et al., Sulfur radical species form gold deposits on Earth. P. Natl. Acad. Sci. USA 2015, 112, 13484-13489.

(54) Pokrovski, G. S.; Tagirov, B. R.; Schott, J.; Hazemann, J. L.; Proux, O., A new view on gold speciation in sulfur-bearing hydrothermal fluids from in situ X-ray absorption spectroscopy and quantum-chemical modeling. Geochim. Cosmochim. Acta 2009, 73, 5406-5427.

(55) Kusebauch, C.; Gleeson, S. A.; Oelze, M., Coupled partitioning of Au and As into pyrite controls formation of giant Au deposits. Sci. Adv. 2019, 5, eaav5891.

(56) Bindi, L.; Moëlo, Y.; Léone, P.; Suchaud, M., Stoichiometric arsenopyrite, FeAsS, from La Roche-Balue quarry, Loire-Atlantique, France: crystal structure and Mössbauer study. Can. Miner. 2012, 50, 471-479.

\section{FIGURE CAPTIONS}

Figure 1. (a) Photograph of the 0.5 emission spectrometer used to collect the HR-SXRF data and to measure the $\mathrm{Au} \mathrm{L}_{3}$-edge HR-XANES and HR-EXAFS spectra on the BM23 microprobe of the ESRF. (b,c) SXRF spectra of pyrite and arsenopyrite measured in total fluorescence-yield (TFY) and high energy-resolution modes. Incident energy, 11930 eV; collection time, 300 s. (d) Fluorescence-yield XANES and HR-XANES of arsenopyrite.

Figure 2. EPMA maps of the distribution of Au and As in arsenian pyrite (a) and arsenopyrite (b). The arsenopyrite grain is compositionally zoned. The color-scale bar indicates the intensity of the Au L $\alpha$ line. White crosses indicate the location of the spots relocated by HR-SXRF (Figure 4) and measured by micro HR-XANES and HR-EXAFS. Map dimensions: pyrite $=100$ x $55 \mu^{2}$, arsenopyrite $=350 \times 130 \mu \mathrm{m}^{2}$. Pixel size: $1 \times 1 \mu \mathrm{m}^{2}$.

Figure 3. Compositions of arsenian pyrite and arsenopyrite from EPMA analyses (Tables S1 and S2) calculated to the formula $(\mathrm{Fe}, \mathrm{Au}, \mathrm{Cu}, \square) \mathrm{S}_{2-x} \mathrm{As}_{x}$ for pyrite and to $(\mathrm{Fe}, \mathrm{Au}, \mathrm{Cu}, \square) \mathrm{As}_{1-x} \mathrm{~S}_{1+x}$ for arsenopyrite, where $\square$ is a cation vacancy. (a,b) Au atomic content x $100(\%)$ against the total number of cations in the unit formula. (c,d) Au content (\%) against As content (\%) in the unit formula of pyrite and arsenopyrite. Note the absence of $\mathrm{Au}$-As correlation and high $[\mathrm{Au}]_{\mathrm{at}} /[\mathrm{As}]_{\mathrm{at}}$ ratio in arsenian 
pyrite, which lies above the solubility limit for gold in $\mathrm{As}^{1-}$-pyrite defined by Reich and coworkers. ${ }^{7}$ Points measured by XANES and EXAFS are in pink. The pyrite point has $0.48 \mathrm{wt} \%$ Au and the arsenopyrite point $0.84 \mathrm{wt} \% \mathrm{Au}$. Points colored in blue were measured in Au-rich growth zones.

Figure 4. HR-SXRF maps of the distribution of Au in arsenian pyrite (a) and arsenopyrite (b) from the Au-rich regions identified by EPMA (Figure 2). Map dimension for pyrite: $290 \times 150 \mu \mathrm{m}^{2}$, pixel size: 5 x $5 \mu \mathrm{m}^{2}$. Map dimension for arsenopyrite: $400 \times 120 \mu \mathrm{m}^{2}$, pixel size: 4 x $4 \mu \mathrm{m}^{2}$.

Figure 5. (a) $\mathrm{Au} \mathrm{L}_{3}$-edge HR-XANES spectra of pyrite, arsenopyrite, and reference compounds $\left(\mathrm{Au}_{2} \mathrm{O}_{3}, \mathrm{AuCl}_{3}, \mathrm{Au}_{2} \mathrm{~S}, \mathrm{Au}\right)$. (b) Theoretical XANES spectra calculated with FDM-FDMNES ${ }^{41,43}$ for Au coordinated to $6 \mathrm{~S}$ and $6 \mathrm{As}$ in pyrite, and to $6 \mathrm{~S}, 3 \mathrm{~S}$ and $3 \mathrm{As}$, and 6As in arsenopyrite after the DFT models shown in Figure 6a and the Au-ligand distances given in Table 1. The energy positions of the calculated spectra, expressed in terms of the photoelectron energy $(0 \mathrm{eV}$ is the Fermi level, Figure 6$)$, were shifted by the ionization energy $(\sim 11919 \mathrm{eV})$ to match approximately those of the experimental spectra, expressed in photon energy.

Figure 6. (a) Polyhedral structure of the Au-pyrite and Au-arsenopyrite clusters used to calculate XANES and $l$-projected density of states (DOS). Pyrite has a cubic structure consisting of cornersharing $\mathrm{FeS}_{6}$ octahedra. ${ }^{36}$ Arsenopyrite has a monoclinic structure consisting of single chains of edgesharing $\mathrm{Fe}\left(\mathrm{As}_{3} \mathrm{~S}_{3}\right)$ octahedra cross-linked by sharing corners. ${ }^{56}$ The octahedron of the absorbing $\mathrm{Au}$ atom is yellow. Calculated XANES spectrum, 5d-DOS of the absorbing Au atom, and valence p-DOS of the $\mathrm{S}$ atoms for the AuS6-pyrite model (b), As atoms for the AuAs6-pyrite model (c), S and As atoms for the $\mathrm{Au}\left(\mathrm{S}_{3} \mathrm{As}_{3}\right)$-arsenopyrite model (d), and As atoms for the AuAs6-arsenopyrite model (e). Plot (e) shows that the $4 p$ orbital occupation for As (or $3 p$ for $S$ ) varies with the Au-As distance (i.e., bond polarity), whereas the orbital energy is essentially independent on the bond length.

Figure 7. (a,b) Au L3-edge micro HR-EXAFS spectra and Fourier transform magnitude of pyrite and arsenopyrite measured on the Au-rich spots imaged on Figures 2 and 4. The peak positions are not corrected for phase shift, and consequently are shifted by $\Delta R \sim-0.3$ to $-0.4 \AA$ relative to structural $R$ distances. (c) Inverse Fourier transform of the second peaks $(R+\Delta R$ window $=2.8-4.0 \AA)$. 
Figure 8. Polyhedral linkage of the $\mathrm{FeS}_{6}$ octahedra in pyrite (a), and $\mathrm{Fe}\left(\mathrm{As}_{3} \mathrm{~S}_{3}\right)$ octahedra in $\mathrm{Au}$-free arsenopyrite (b). The $\mathrm{FeS}_{6}$ octahedra are linked together by $\mathrm{S}_{2}$ dimers and the $\mathrm{Fe}\left(\mathrm{As}_{3} \mathrm{~S}_{3}\right)$ octahedra by SAs dimers. Yellow: S; dark red: As.

Figure 9. Au $\mathrm{L}_{3}$-edge micro HR-EXAFS spectra and Fourier transform magnitudes of pyrite (a) and arsenopyrite $(b, c)$ with fits. 
Table 1. Crystallographic structure of pyrite and arsenopyrite, DFT models of Au-pyrite and Au-arsenopyrite, and EXAFS parameters

\begin{tabular}{|c|c|c|c|c|}
\hline Mineral and structure & Bond & $\mathbf{C N}^{a}$ & $\mathbf{R}^{b}, \AA$ & $\sigma^{c}, \AA$ \\
\hline Pyrite & Fe-S & 6 & 2.26 & - \\
\hline \multirow[t]{3}{*}{ Crystal structure } & $\mathrm{Fe}-\mathrm{S}$ & 6 & 3.45 & - \\
\hline & $\mathrm{Fe}-\mathrm{S}$ & 2 & 3.61 & - \\
\hline & $\mathrm{Fe}-\mathrm{Fe}$ & 12 & 3.83 & - \\
\hline Au-substituted pyrite & Au-S & 6 & 2.47 & - \\
\hline \multirow[t]{3}{*}{ DFT model } & Au-S & 6 & 3.46 & - \\
\hline & Au-S & 2 & 3.65 & - \\
\hline & $\mathrm{Au}-\mathrm{Fe}$ & 12 & 3.89 & - \\
\hline Arsenian pyrite & Au-S & 5.7 & 2.41 & 0.049 \\
\hline EXAFS structure & Au-S & 7.6 & 3.50 & $0.068^{e}$ \\
\hline$\Delta E_{0}=7.0 \mathrm{eV} ; \operatorname{Res}^{d}=9.2$ & $\mathrm{Au}-\mathrm{Fe}$ & 11.9 & 3.85 & $0.068^{e}$ \\
\hline Arsenopyrite & $\mathrm{Fe}-\mathrm{S}$ & 3 & 2.23 & - \\
\hline \multirow[t]{6}{*}{ Crystal structure } & Fe-As & 3 & $2.37-2.41$ & - \\
\hline & $\mathrm{Fe}-\mathrm{Fe}$ & 1 & 2.73 & - \\
\hline & $\mathrm{Fe}-\mathrm{S}$ & 4 & $3.68-3.76$ & - \\
\hline & Fe-As & 4 & $3.69-3.80$ & - \\
\hline & $\mathrm{Fe}-\mathrm{Fe}$ & 1 & 3.74 & - \\
\hline & $\mathrm{Fe}-\mathrm{Fe}$ & 6 & $3.94-4.10$ & - \\
\hline \multirow{7}{*}{$\begin{array}{l}\text { Au-substituted } \\
\text { arsenopyrite } \\
\text { DFT model }\end{array}$} & Au-S & 3 & $2.43-2.46$ & - \\
\hline & Au-As & 3 & $2.47-2.49$ & - \\
\hline & $\mathrm{Au}-\mathrm{Fe}$ & 1 & 3.14 & - \\
\hline & Au-S & 4 & $3.62-3.83$ & - \\
\hline & Au-As & 4 & $3.78-3.95$ & - \\
\hline & $\mathrm{Au}-\mathrm{Fe}$ & 1 & 3.48 & - \\
\hline & $\mathrm{Au}-\mathrm{Fe}$ & 6 & $3.97-4.10$ & - \\
\hline Arsenopyrite & Au-As & 5.6 & 2.52 & 0.055 \\
\hline EXAFS model-fit 1 & $A u-S$ & $4.3^{f}$ & 3.73 & $0.033^{e}$ \\
\hline$\Delta E_{0}=7.5 \mathrm{eV} ;$ Res $=4.7$ & Au-As & $3.7^{f}$ & 3.94 & $0.033^{e}$ \\
\hline Arsenopyrite & Au-As & 5.6 & 2.52 & 0.055 \\
\hline EXAFS model-fit 2 & Au-S & $8^{g}$ & 3.77 & $0.069^{e}$ \\
\hline$\Delta E_{0}=7.7 \mathrm{eV} ; \operatorname{Res}=4.8$ & $\mathrm{Au}-\mathrm{Fe}$ & $4^{g}$ & 4.00 & $0.069^{e}$ \\
\hline
\end{tabular}


a

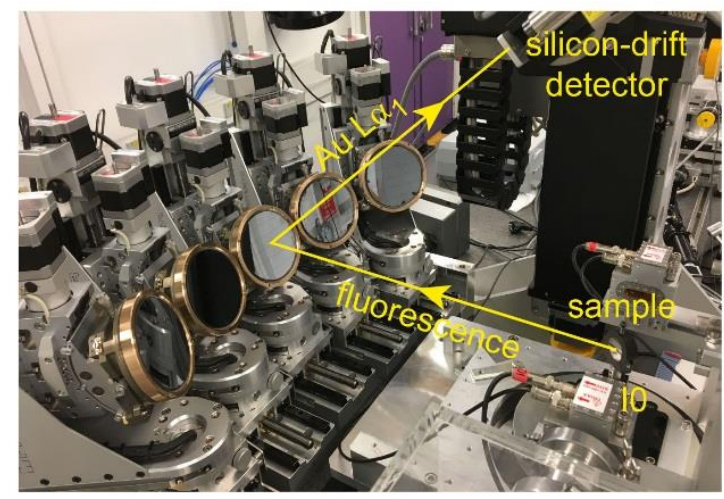

c

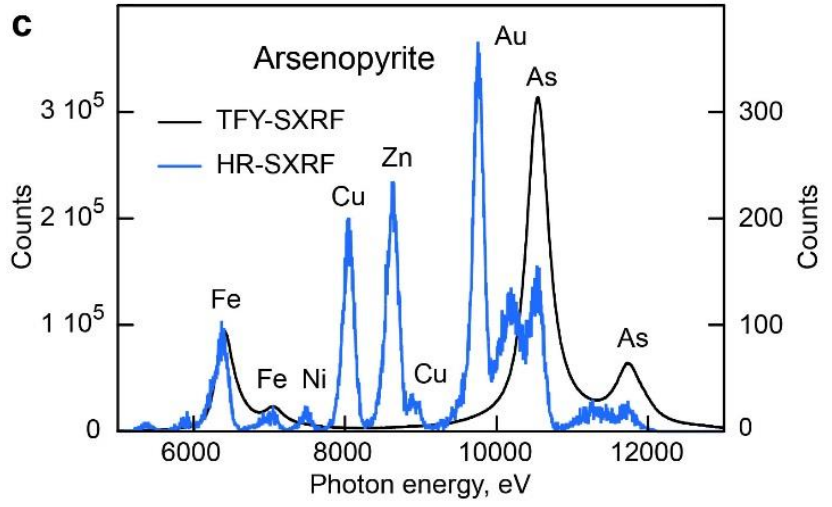

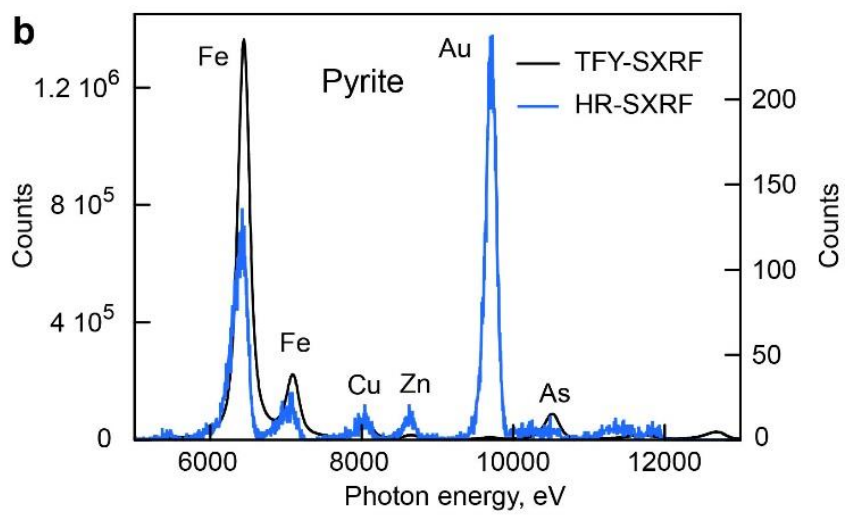

d

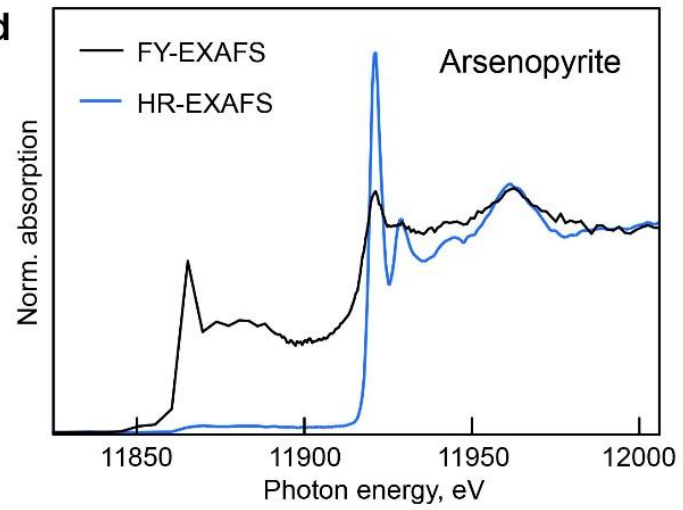

Figure 1

Please, print on two columns with a width of $15 \mathrm{~cm}\left(6^{\prime \prime}\right)$, thank you
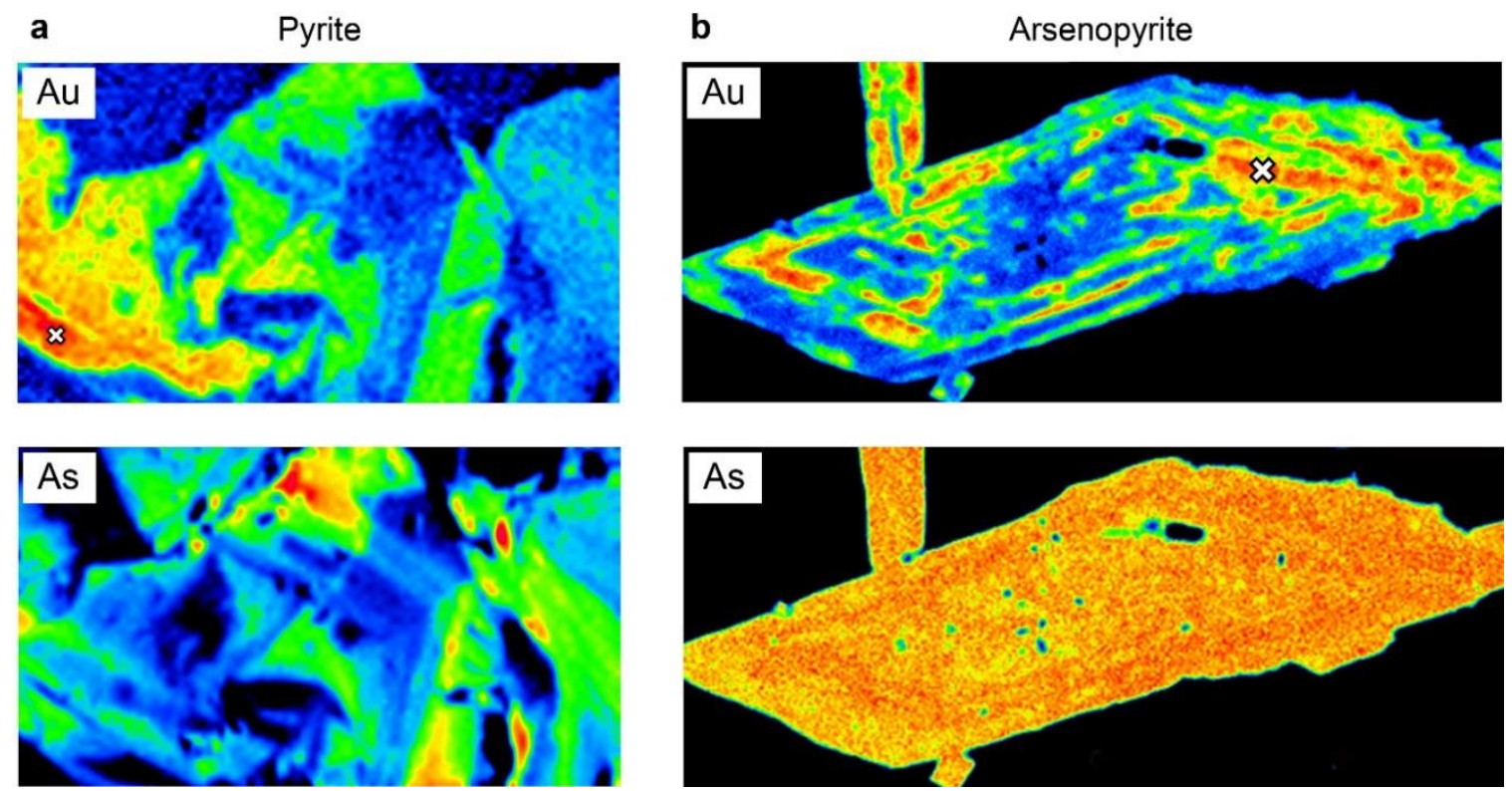

Figure 2

Please, print on two columns with a width of $15 \mathrm{~cm}\left(6^{\prime \prime}\right)$, thank you 

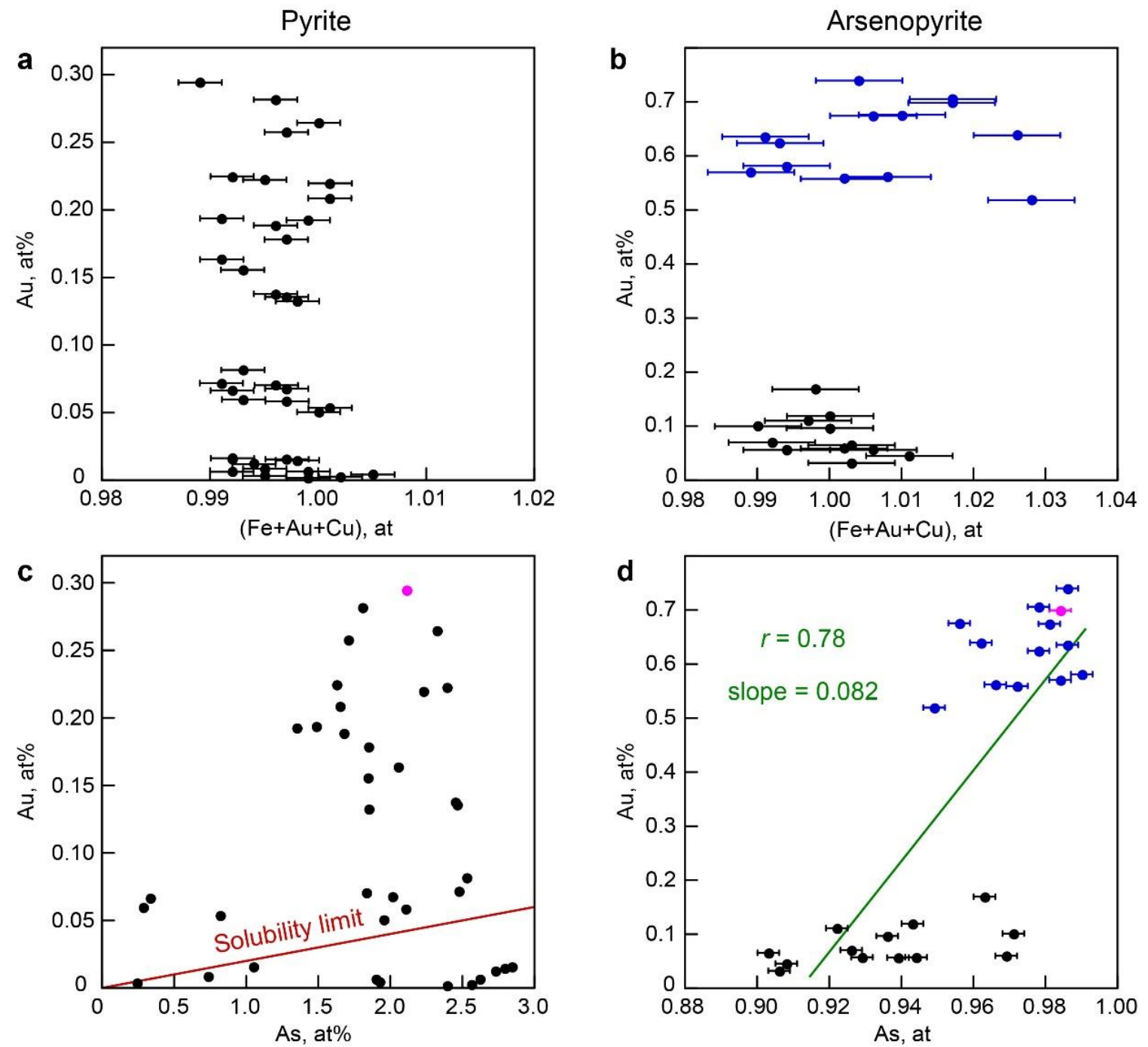

Figure 3

Please, print on two columns with a width of $15 \mathrm{~cm}\left(6^{\prime \prime}\right)$, thank you 

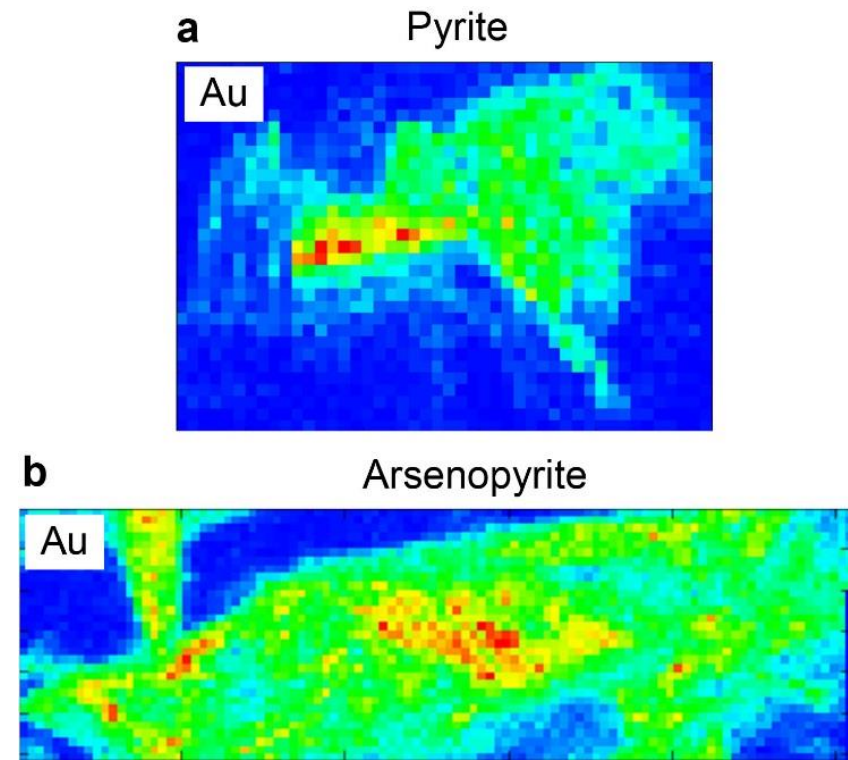

Figure 4

Please, print to fit the full width of one column, thank you 

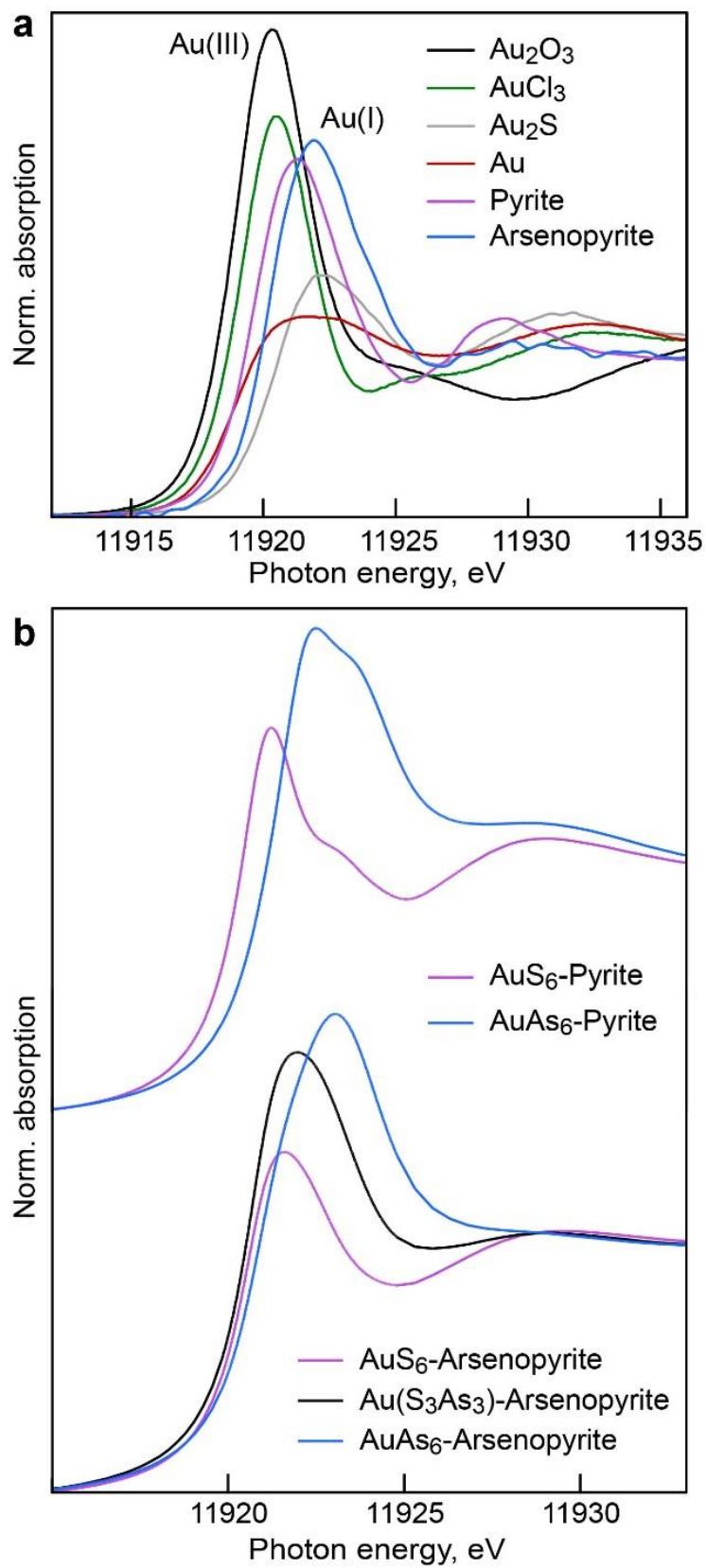

Figure 5

Please, print to fit the full width of one column, thank you 
a

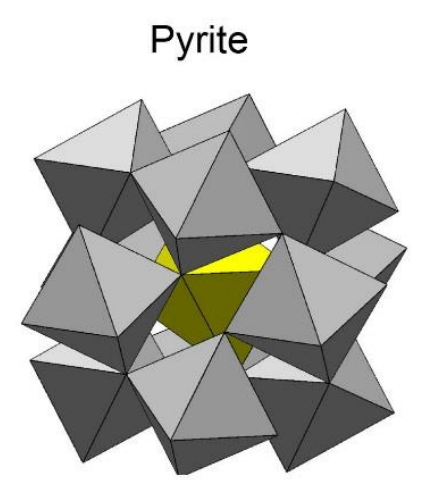

Arsenopyrite

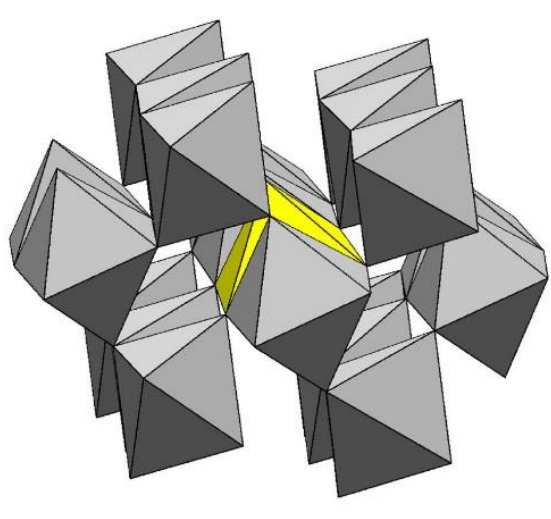

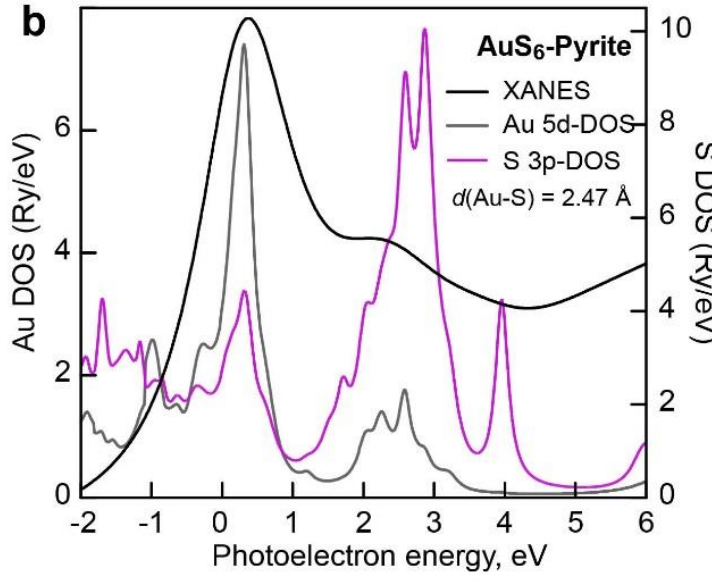

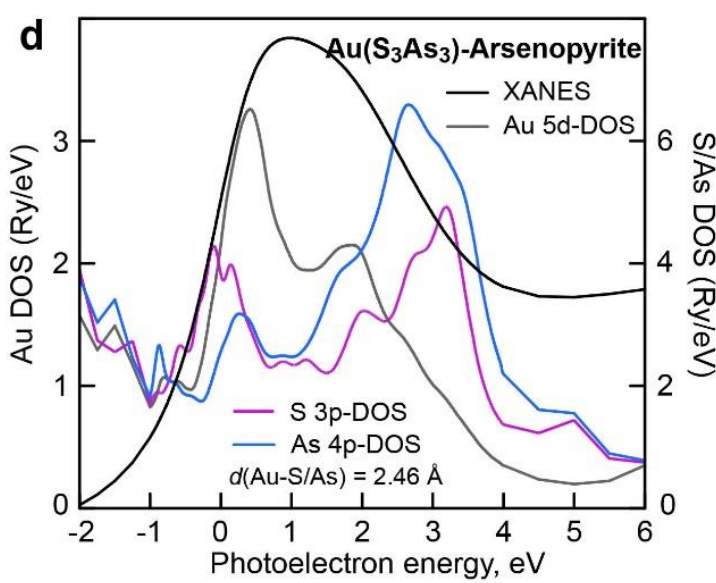

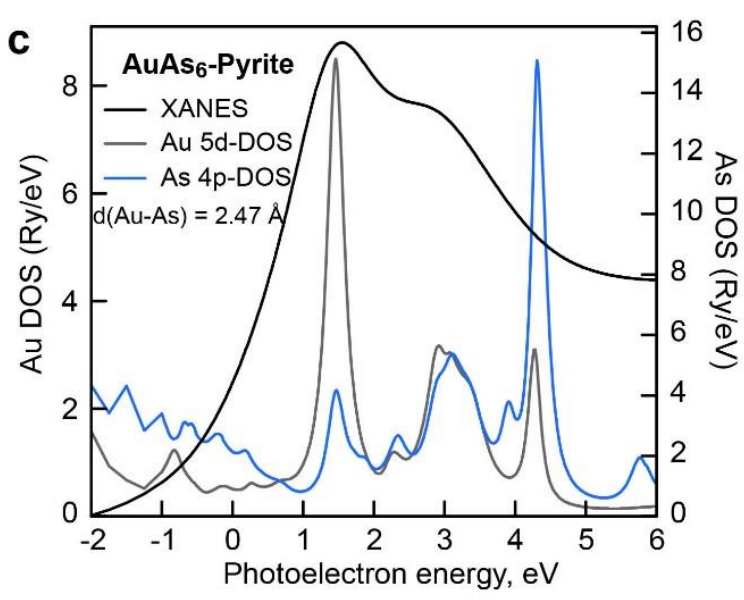

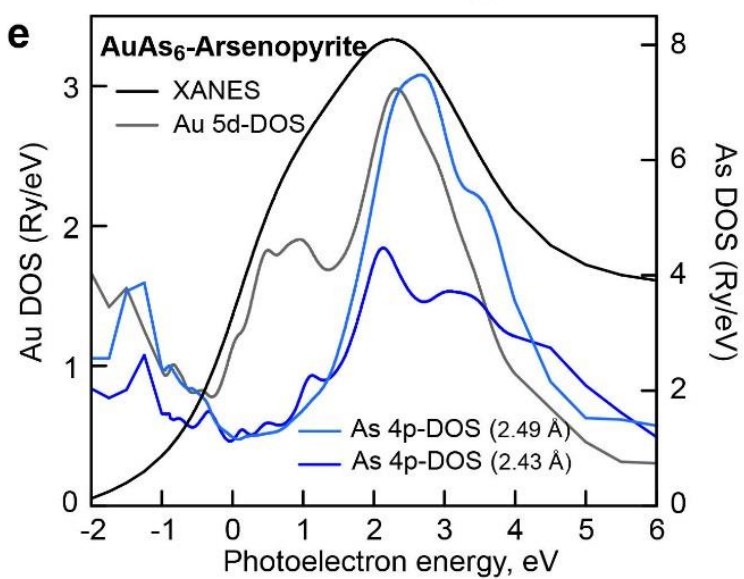

Figure 6

Please, print to fit the full width of two columns, thank you 

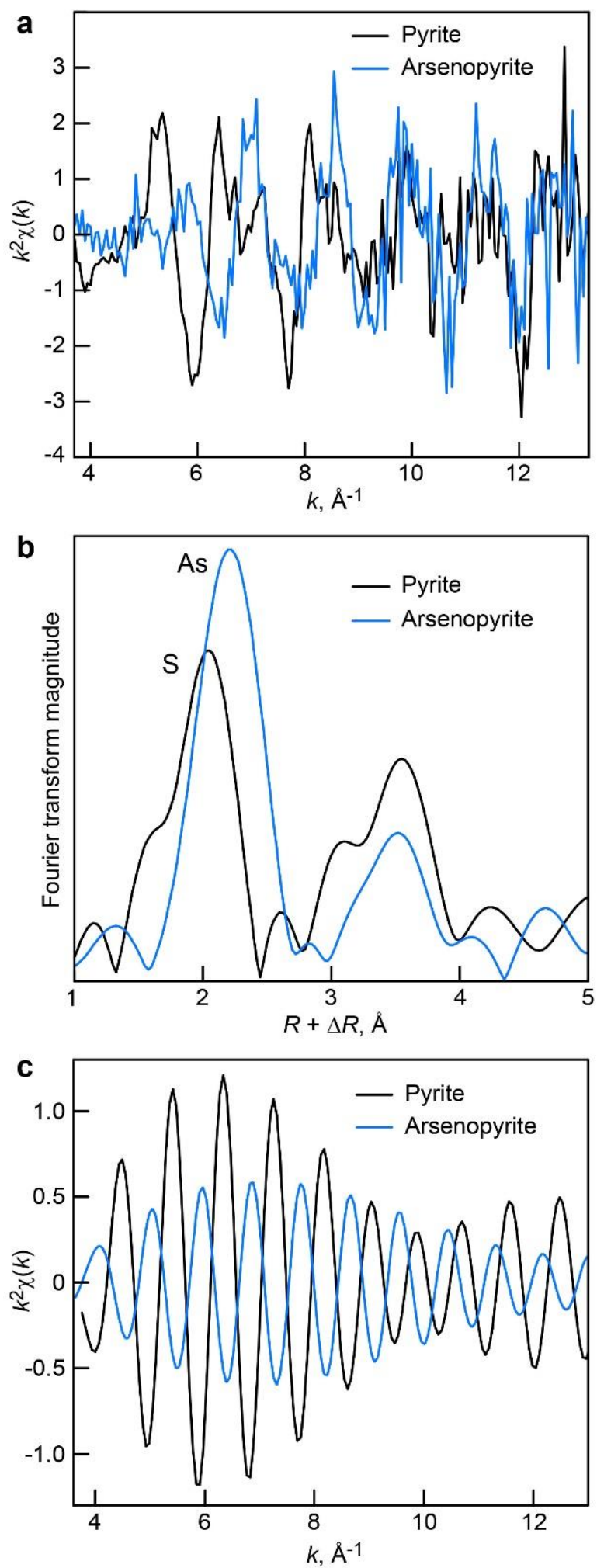

Figure 7

Please, print to fit the full width of one column, thank you 

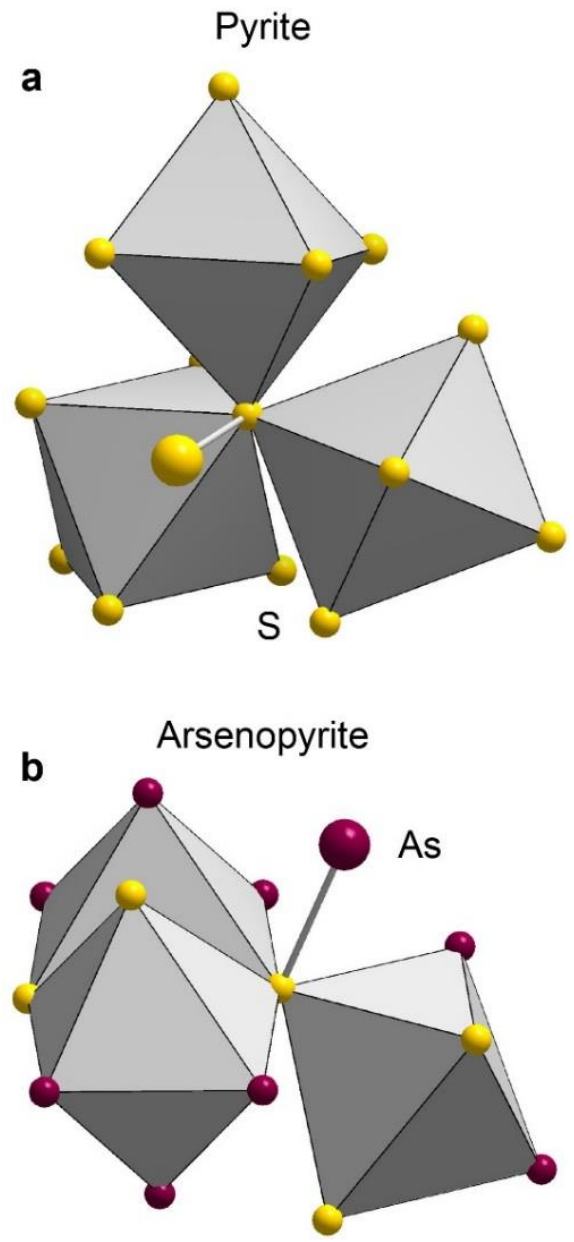

Figure 8

Please, print with a width of $5 \mathrm{~cm}\left(2^{\prime \prime}\right)$, thank you 

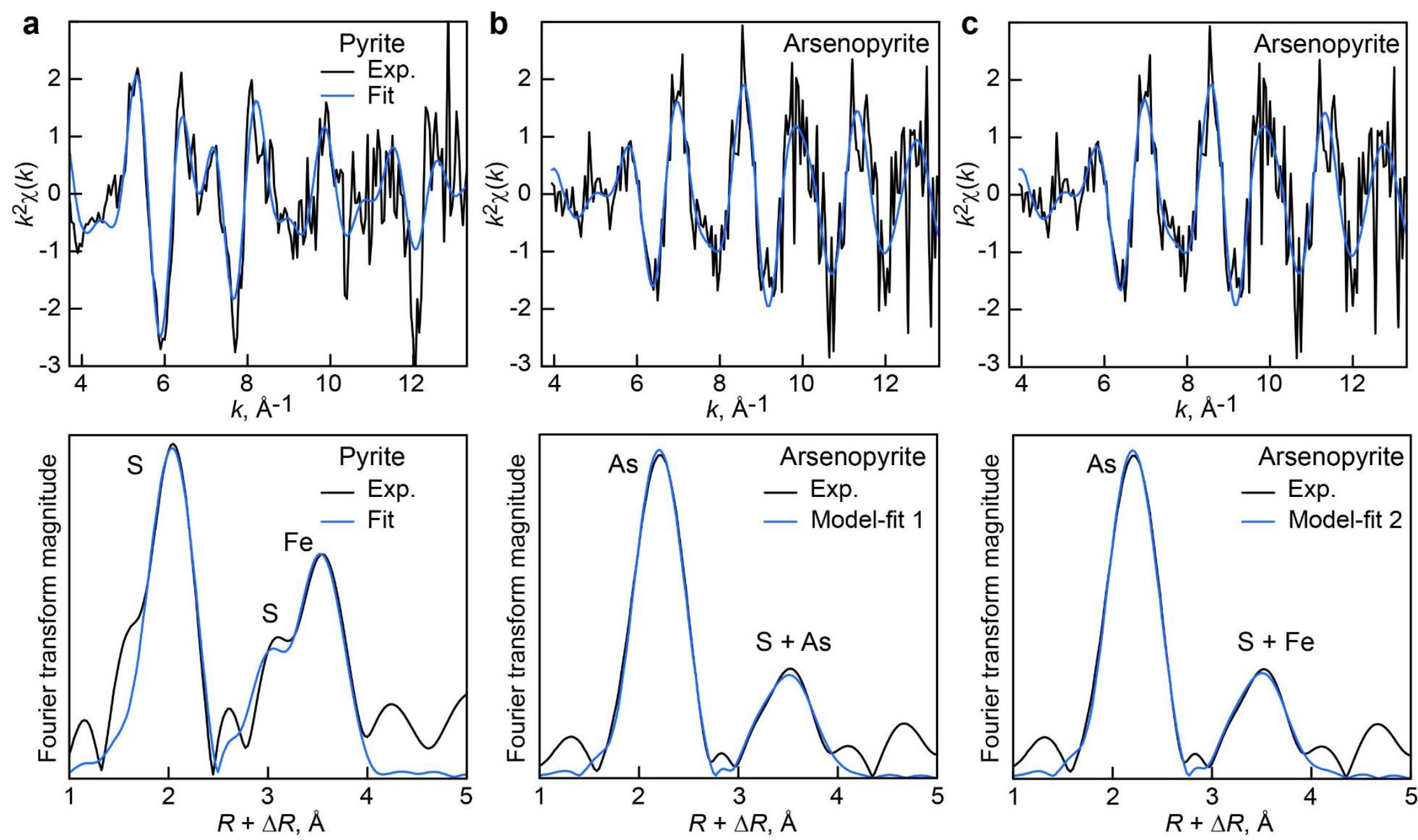

Figure 9

Please, print to fit the full width of two columns, thank you 


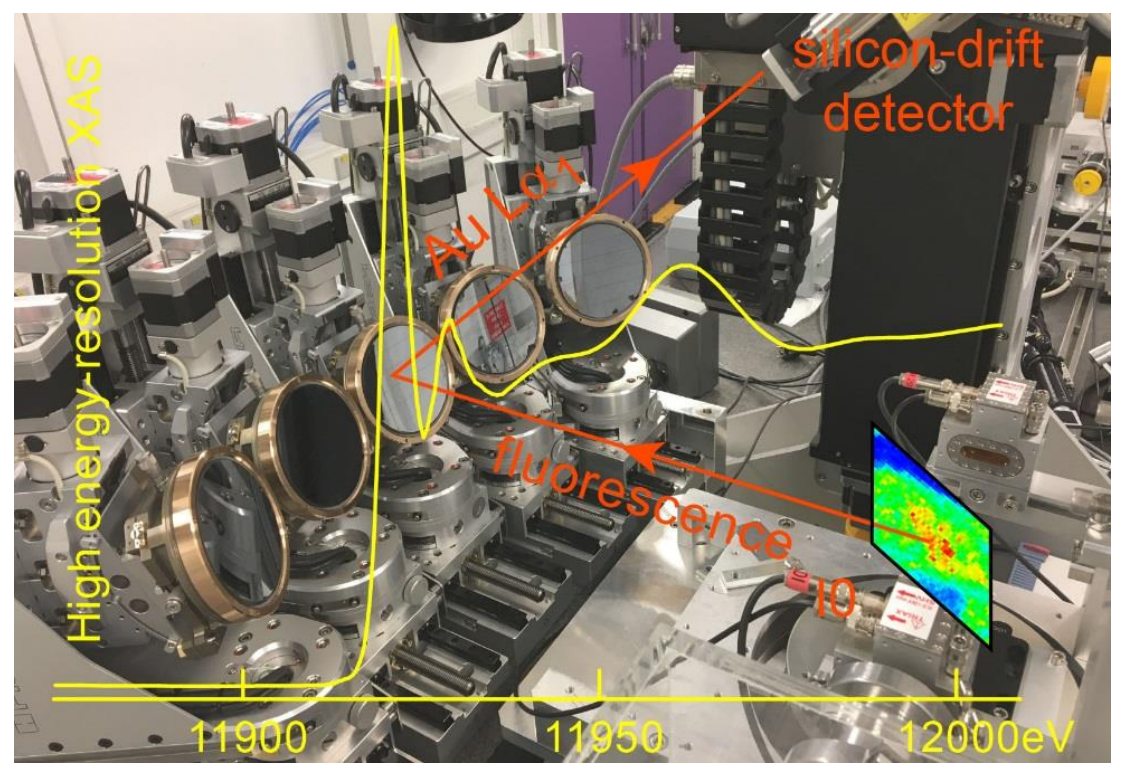

TOC graphic 